February 12, 2013 10:17 AM

\title{
U.S. will reduce the number of troops in Afghanistan by 34,000
}

President Obama will announce in his State of the Union Address Tuesday night that by this time next year 34,000 troops will have returned to the United States, according to a senior administration official.

Anita Kumar - McClatchy Newspapers

o LinkedIn

o Google +

o Pinterest

o $\underline{\text { Reddit }}$

o $\underline{\text { Print }}$

- Order Reprint of this Story

President Obama will announce in his State of the Union Address Tuesday night that by this time next year 34,000 troops will have returned to the United States, according to a senior administration official.

That will reduce the number of troops in Afghanistan by half.

"Further reductions will continue through the end of 2014 as Afghans take full responsibility for their security," the official said.

Obama met with Afghan President Hamid Karzai in Washington last month where the two talked about reducing the U.S. troops. Afghan troops will lead combat missions starting in spring.

"The president will not be making any further announcements about troop numbers tonight, nor has he made any decisions beyond the one he is announcing," the official said.

Read more here: http://www.mcclatchydc.com/news/politics-

government/article24744721.html\#storylink=cpy 